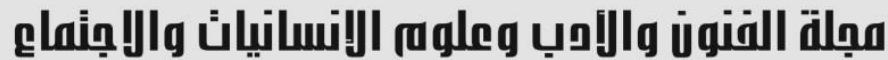

Journal of Arts, Literature, Humanities and Social Sciences

www.jalhss.com

Volume (54) July 2020

العدد (54) يوليو 2020

\section{Linguistic and Cultural Characteristics of Compliments in Russian and English Discourse}

\author{
Marharyta Alsultan \\ Department of English - College of Education and Languages \\ Lebanese French University - Kurdistan Region / Erbil - Iraq \\ Email: alsultan.Ifu@gmail.com
}

\begin{abstract}
The given research is entitled "Linguistic and cultural characteristics of compliments in Russian and English discourse". It aims at determining the linguistic and cultural characteristics of Russian and English speech act such as a compliment. In the course of the study the main role is dedicated to the analysis of the means of expression of compliment speech acts; identification of the main forms and types of compliment. Moreover, the author determines the place of compliment in speech etiquette and speech behaviour, recipients and addressees of the compliment and their intentions in Russian and English linguistic cultures. Thus, the main difference between Russian and English speech acts of compliment is the different degree of correspondence of the feelings and emotions of the recipient of the compliment. Therefore, the relationship between the manifestation of emotions and feelings experienced in this case is not always direct and unambiguous. Accordingly, in intercultural communication, it is necessary to possess the skills of the correct interpretation of emotions and their correct interpretation to ensure effective communication.
\end{abstract}

Keywords: Speech Act, Compliment, Praise, Addressee, Intercultural Communication, Linguistic Discourse. 


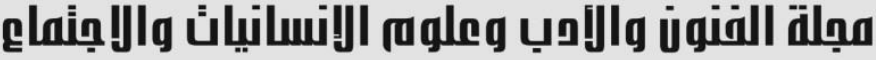 \\ Journal of Arts, Literature, Humanities and Social Sciences \\ www.jalhss.com \\ Volume (54) July 2020 \\ العدد (54) يوليو 2020}

\section{Introduction}

The relevance of this study is determined by the anthropocentric and communicative orientation of modern linguistics. The problem of the successful implementation of language communication is solved largely with the help of complimentary statements. A compliment as one of the attributes of speech behaviour attracts the attention of many researchers. At present, studies from various fields of humanitarian knowledge are devoted to the study of compliment: pragmatics, linguodidactics, linguistics, cultural studies, text theory, rhetoric, sociology (N.N. Germanova, O.S. Issers, V.I. Karasik, V.V. Leontyev, I.S. Morozova, E.S. Petelina and others).

A compliment is an integral part of speech etiquette. As a form of speech etiquette, a compliment is used in various speech situations: during a meeting, farewell, congratulations, etc. Such forms of verbal communication are nationally determined, have gender characteristics and fit into the actual problems of modern linguistics.

The aim of the research is to determine the linguistic and cultural characteristics of Russian and English compliments.

In accordance with the aim, the following tasks are set: to consider acts of speech expression in modern linguistics, to identify the main forms and types of compliment; to determine the place of compliment in speech etiquette and speech behaviour, recipients and addressees of the compliment and their intentions in Russian and English linguistic cultures.

The artistic works of Russian and British writers of the XIX century served as the research material for this work: I.A Goncharov, I.S. Turgenev, A.P. Chekhov, J. Austin, O. Wilde. The choice of material is due to the fact that it is the period of the late 19th century that is characterized by the widespread use of compliment as a form of speech etiquette. The total volume of the analyzed material is 1600 pages, of which the volume of complimentary statements is 50 units for English material, 50 units for Russian.

The object of the research is the linguistic and cultural features of the complimentary utterances in Russian and English linguistic cultures in a comparative aspect.

The subject of this study was contexts with stereotypical statements of compliments in Russian and English linguistic cultures.

The methodological basis of the study was the works in the field of:

- theories of speech acts (N.D. Arutyunova, G.P. Grice, D. Davidson, J. Austin, E.V. Paducheva, J. Searle, V.N. Telia and others);

- linguistic, cultural and intercultural communication (L.G. Vedenina, E.M. Wolf, I.M. Kobozeva, V.A. Maslova, E.V. Paducheva, V.N. Telia, S.G. Ter-Minasova, N.I. Formanovskaya and others);

- gender linguistics (E.I. Goroshko, A.V. Kirilina, V.V. Leontiev, E. Mitrokhina, I.S. Morozov).

In accordance with the aim, objectives and specifics of the research material, the following methods were used in the work: general scientific (observation, classification, description, modeling); linguistic (component analysis method, comparative-matching method, comparative and descriptive methods, dictionary 


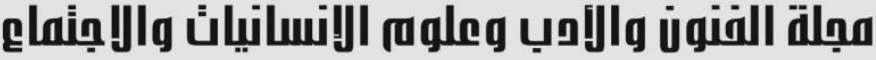 \\ Journal of Arts, Literature, Humanities and Social Sciences www.jalhss.com \\ Volume (54) July 2020 \\ العدد (54) يوليو 2020}

definition method, definitive-matching method, quantitative method, contextual and stylistic methods).

Compliment as a phenomenon can be studied from different points of view: psychology, sociology, cultural studies, linguistics and other sciences. Each of these sciences studies praise and compliment through its system of concepts and values. Psychology studies a compliment as a kind of "psychological stroking" that helps a person achieve the location of the interlocutor and promotes effective interpersonal interaction. Sociology considers compliment as a component of the creation and development of a person's relationship with the surrounding society and the individual's construction of his social space. For culturology, a compliment is, first of all, an element of the culture of a given ethnos, its etiquette, moral standards, traditions and customs accepted in society. The theory of speech acts as the main aspects distinguishes speech action, psychological interaction and the way of language implementation of speech action as a compliment.

The science that arose at the junction of the sciences listed above - pragmatics, or pragmatic linguistics - incorporates all these aspects and facets of praise and compliment and makes it possible to comprehensively study this variety of speech acts both within the framework of one communicative culture and in intercultural communication.

From the point of view of rhetoric, praise and compliment are included in the system of genres of epidemiological speech, because these statements represent an inspiring, solemn, eulogy.

\section{Compliment as a type of speech act in Russian and English linguistic discourse}

The attempts to study evaluative statements have already been made in linguistics. Compliment and praise are qualified as the most important speech genres with positive evaluative semantics.

The specifics of Russian and English culture, especially the national character of the representatives of the two linguistic and cultural communities determine the differences in the evaluative consciousness of Russians and English. Moreover, the national-cultural specificity of speech acts of praise / compliment in Russian and English speech communication is manifested both in the content of the statements and in their form.

Initially, the verb "complire", derived from the verb "plire" by means of prefix being added, was borrowed from the Latin language by the Old French and Northern Spanish languages. It means "fill", "inspire", "fulfill", "perform", "complete", etc.

At the beginning of the 18th century, the token "compliment" was included in the lexical structure of the Russian language and first appeared in the papers of Peter I in 1701-1702. But the question of what language Russian borrowed the word "compliment" from is still difficult to answer unequivocally. Most dictionaries claim that this is a French word, and disputes are conducted mainly on the issue of its direct or indirect borrowing. In the late 19th and early 20th centuries, the identification of a compliment with a bow, and then with a greeting dating back to the Spanish language, 


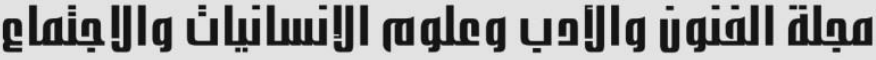 \\ Journal of Arts, Literature, Humanities and Social Sciences www.jalhss.com \\ Volume (54) July 2020 \\ العدد (54) يوليو 2020}

was lost by the Russian language, and compliments in the meaning of the bow were used only according to tradition: "when a new guest arrives, they get up and make a compliment, and even in the case when the newcomer does not notice this, and repeat this bow at the next meeting with him. While in conversation with someone, they bow to the new guest, turning to him with his whole body, but not at all sideways. With such compliments, in any case, they do not become their backs to their former interlocutor" (Serebryakova, 2002).

In the compliment, considered as a speech act, three main aspects should be distinguished: speech action, psychological interaction and the way of language implementation of speech action. The speech action model integrates the provisions of the theory of Speech acts, the theory of speech activity and the concept of politeness. We understand a complimentary utterance as a language means of achieving qualitatively different (verbal and non-verbal) communicative goals, as the realization of a speech action, which is a complex unity of a locative act, illocutionary act, perlocutionary act and social action.

The illocutionary goals of a compliment are:

1) to express the positive intentional state of the speaker, the representative content of which is an explicit or implicit positive value judgment;

2) to express the intention / desire / desire of the speaker to please the addressee;

3) to express a positive attitude of the speaker to the addressee.

The illocutionary act of compliment is characterized by a wide range of expressed intentional states of the speaker - not only approval and admiration, but also respect, sympathy, love, affection, enjoyment, pleasure, etc.

The illocutionary act of a compliment is considered insincere when at least one of the expressed intentional states does not correspond to the real one, and also when a positive value judgment, which makes up the propositional content, does not correspond to the real value.

The perlocutionary goal of a compliment is mainly to arouse a positive emotional reaction in the addressee, to give him/her the feeling of pleasure. The impact on the recipient of the compliment is based on the satisfaction of his vital need to be recognized and appreciated by others. The quality of the perlocutionary effect, and accordingly the success of the perlocutionary act, is due to such aspects of the illocutionary act of compliment as the object of a positive assessment, the social-role status of the communicants and the nature of the relationship between them, the circumstances in which the illocutionary act of compliment is performed. Perlocutionary acts of compliment can be not only intentional (intentional), but also non-intentional. Non-intentional perlocutionary compliment acts occur in situations where the positive reaction of the addressee caused by the utterance was not included in the speaker's goals.

Compliments as social actions are divided into two main classes: etiquette and instrumental. The classification criterion in this case is the nature of the social goal of the compliment. The general social goal of all etiquette compliments is to maintain non-antagonistic relationships between communicants, while the invariant goal of instrumental compliments is to change the behavior of the communication partner. 


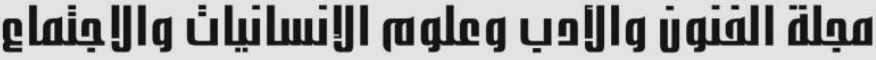 \\ Journal of Arts, Literature, Humanities and Social Sciences www.jalhss.com \\ Volume (54) July 2020 \\ العدد (54) يوليو 2020}

So, a compliment involves social and emotional speech exposure. Social speech impact is a special communication situation in which there is no transfer of information, but certain social acts are carried out. The sender of the message is guided by a speech-acting, not communicative purpose. When we compliment the interlocutor, we, as a rule, do not set ourselves the goal of informing, informing him of one or another of his merits, but trying to attract him to himself, to express his admiration for his merits and abilities, to force him to carry out any actions, to agree for anything, etc. Emotional speech exposure is aimed at interpersonal subjectiveemotional relationships. The main motive for the target recipients of compliments is to improve the emotional state of the recipients.

Thus, compliments combine the characteristics of different speech acts. They may combine the features of representative, expressives and phatic communication. But since the leading characteristic of a compliment is the evaluative nature of this speech act, we consider it in the category of expressives. The compliment refers to noninformative speech actions, expressing the regulatory, index and emotional-evaluative content.

To achieve the objectives of our research, we accept the definition of a speech act of praise / compliment as a separate speech utterance that serves to express the opinion (often positive and less often - pseudo-positive) of the addressee about his addressee or a third party who is not a direct participant in communication, and pronounced in direct communication interlocutors to achieve certain goals by the addressee.

To identify common patterns and differences in the use of speech acts of praise / compliment in Russian and English communicative cultures, we have defined criteria for their comparison. Based on the developed comparative criteria, a classification of compliments was made, which served as the basis for a comparative analysis.

In complimentary interaction, it is the subject (addressee) who determines the communication strategy, the specificity of which finds expression in the system of attitudes - interpersonal and impersonal. At the same time, interpersonal attitudes can be focused on oneself, on the addressee, on the listener and on third parties. Accordingly, in a complimentary interaction, one can single out a compliment to the addressee, a compliment to oneself, a compliment to the listener (i.e., to a third party that is present), a compliment to a third party who is not present during communication, but who influences the nature of speech exchange, since this person may be included in the scope interests of either the speaker or the addressee (Antipov, 1989).

Based on the foregoing, the criteria for the typology of speech acts of praise / compliment should determine:

1) the direct orientation of the statement to the addressee present in the communicative space, acting as the recipient of a compliment;

2) the indirect orientation of the utterance to the addressee present in the communicative space, acting as the recipient of a compliment, but not a participant in the interaction; 


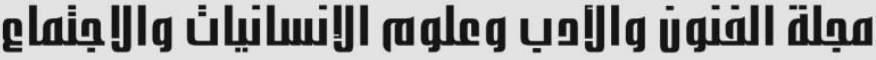 \\ Journal of Arts, Literature, Humanities and Social Sciences www.jalhss.com \\ Volume (54) July 2020 \\ العدد (54) يوليو 2020}

3) the orientation of the statement to the recipient of the compliment, which is absent in the communicative space (in this case, the recipient participates in interaction with another subject - the recipient of the statement is not a complimentary character);

4) the orientation of the compliment to the addressee (if the addressee and the addressee coincide in one person) in interaction with another subject (the addressee of an uncomplimentary speech);

5) the orientation of the compliment to a single or multiple (collective) addressee;

6 ) the orientation of the compliment on the internal or external characteristics of the addressee;

7) the aggregate or non-aggregate of a compliment;

8) the stylized or non-stylized compliment;

9) consistency / inconsistency of the deep and surface semantics of compliment;

10) a compliment or pseudo-compliment (Serebryakova, 2002).

Thus, although all compliments are evaluative and often pronounced expressive judgments, their real semantics allows us to highlight a number of criteria for their classification. At the same time, speech acts of praise / compliment are implemented in the Russian and English languages in a non-identical way, corresponding to different characteristics of speech acts.

Based on a preliminary analysis of the factual material and the study of theoretical prerequisites for the national character and communicative behavior of Russians and English, we have summarized the above typological criteria, forming a classification of compliments that serves to identify the features of this type of speech acts in two communicative cultures. So, in speech acts of praise / compliment, the nationalcultural features of the Russian and English ethnic communities can be expressed:

- in objects of compliments;

- at its addressees and addressees;

- in the ways of implementing a compliment;

- in the language of compliment;

- in relation to the compliment and reaction to it.

We took these criteria as a basis for the classification of compliment and analysis of general patterns and distinctive features of the implementation of the speech acts we are considering in the English and Russian communicative cultures.

A compliment may evaluate individual traits of a person's character, his appearance and clothing, his internal moral qualities, abilities, and other virtues. The list of potential objects of praise and compliments in both Russian and English communicative culture is quite large, but, of course, a number of objects are the most common in complimentary statements. Our task is to identify these objects and determine the frequency of use of the Russian and English linguistic personality of speech acts with various objects of praise / compliment.

A number of works and studies are devoted to compliment as a rhetorical genre in modern science. Some of them are directly focused on the study of compliment in Russian and English communicative culture, which is most consistent with the purpose of our work. Therefore, we use the best practices in this area to characterize objects of complimentary statements. 


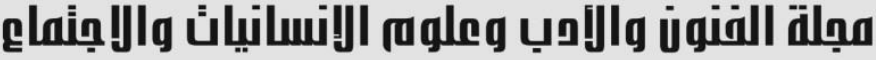 \\ Journal of Arts, Literature, Humanities and Social Sciences www.jalhss.com \\ Volume (54) July 2020 \\ العدد (54) يوليو 2020}

The results of a study by R. Serebryakova of praise and compliment in Russian and English communication indicate the differences in the estimated communicative consciousness of Russian and English (Serebryakova, 2002). The results of the study are shown in Table 1.

\begin{tabular}{|l|l|l|}
\hline \multirow{2}{*}{ Type of compliment } & \multicolumn{2}{|l|}{$\%$ of the total number of speech acts } \\
\cline { 2 - 3 } & $\begin{array}{l}\text { Russian } \\
\text { communicative } \\
\text { culture }\end{array}$ & $\begin{array}{l}\text { communicative } \\
\text { culture }\end{array}$ \\
\hline $\begin{array}{l}\text { Compliments about the appearance of a } \\
\text { person }\end{array}$ & $37 \%$ & $21 \%$ \\
\hline $\begin{array}{l}\text { Compliments that assess professionalism or } \\
\text { specific abilities }\end{array}$ & $19 \%$ & $20 \%$ \\
\hline $\begin{array}{l}\text { Summarizing compliments (compliments } \\
\text { characterizing the personality as a whole) }\end{array}$ & $16 \%$ & $10 \%$ \\
\hline Compliments about inner moral qualities & $10 \%$ & $24 \%$ \\
\hline Compliments about Intellectual Abilities & $9 \%$ & $13 \%$ \\
\hline $\begin{array}{l}\text { Other compliments (compliments regarding } \\
\text { age, name compliment, compliment to home, } \\
\text { home environment and others) }\end{array}$ & $9 \%$ & $12 \%$ \\
\hline
\end{tabular}

Table 1. Analysis of the frequency of praise / compliments in Russian and English communicative cultures, depending on the object of praise / compliments

\section{Data Analysis and Findings}

Thus, in the framework of our study, it was revealed that compliments prevail in a person's appearance in Russian communicative culture, while compliments in man's internal, moral qualities dominate in the English communicative culture. The main factors determining these national-cultural differences in the use of compliments, in our opinion, are the non-identity of hierarchical value systems in comparable linguistic cultures and differences in the principles and norms of Russian and English etiquette cultures.

However, quite a lot of attention is paid to compliments of appearance in English speech communication - this type of compliments in English culture is in the second place. It is quite obvious that in both Russian and English communicative cultures compliments about appearance are used mainly in informal situations of communication. In business communication, compliments about the appearance of the interlocutor are uncommon and can be considered as a sign of bad taste. Some authors, in particular S. Ilyinsky, argue that generally "compliments regarding the 


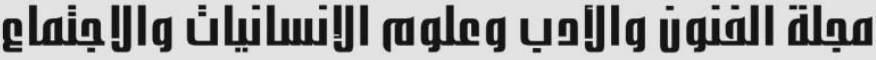 \\ Journal of Arts, Literature, Humanities and Social Sciences \\ www.jalhss.com \\ Volume (54) July 2020 \\ العدد (54) يوليو 2020}

appearance and physical properties of the interlocutor such as" how you lost weight "or" how tall you are "are considered as vulgar" (Glazunov, 2000).

Despite this, the above research results and the material that we studied indicate the actual high frequency of use of this type of speech act of praise / compliment in both communicative cultures.

We have also considered the examples of such statements taken from the texts of works of Russian and English fiction:

E.g. «Ты красива, и к тому же в его вкусе...» (Щемелинин К.С. «Я»).

«Я особенно люблю вот таких, как ты, симпатичных» (Куприн А.И. «Яма»).

«Как она была хороша, как необыкновенно красива!» (Алешкин П. «Русская трагедия»).

"I've always wanted to meet you," she gushes. Then she stands back and says, "You are as pretty as everyone says" (Bushnell C. "Four Blondes").

"In the first place, you're the most beautiful woman I've ever seen..."

(Wharton E. 'Summer').

"You look very beautiful in red, minx." (Hern C. "Miss Lacey's Last Fling").

In the above examples, compliments are used regarding the general appearance of the addressee or a third party that is not participating in the communication.

As for compliments about certain elements of appearance, body parts, they are often used in both Russian and English communication. Such compliments characterize the eyes or hands, face or hair, etc .:

E.g. «Бог мой, я ведь и не представлял, какие у тебя красивые глаза! - вдруг сказал он. - Цвета моря» (Королева А. «Глаза цвета моря»).

«Это...просто загляденье. Удивительно ладная фигура,...красивые руки и серые глазищи в пол-лица» (Дивов О. «Братья по разуму»).

«...красавица Вера: каштановые локоны, голубые глаза» (Герцева А. «Красная сирень»).

"You have really nice eyes, don't you? Misshaped though, but nice" (Ostdick N. "Ronald Jones Loves Me").

"I would tell you how the soft red silk enhances the natural flush of your perfectly sculpted cheeks - cheeks softer than silk, petal-soft..." (Hern C. "Miss Lacey's Last Fling").

"I would tell you... how the fiery color echoes the tantalizing hints of auburn caught by the candlelight in your glorious hair - thick, luxurious hair..." (Hern C. "Miss Lacey's Last Fling").

Among compliments to the person's internal moral qualities, having the highest frequency of use in English speech communication, compared with other types of speech acts of praise / compliment, compliments to kindness and other traditional virtues - generosity, honesty, modesty, courage, religiosity, are the most productive. E.g. "Dear Sally, what I like about you is your beautiful honesty" (Lessing D. "England Versus England").

"You've been wonderfully kind to me" (Wharton E. "Summer").

"...they are some of the finest and the kindest human beings on the face of the earth!" (Wharton E. "Summer"). 


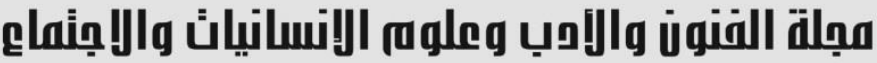 \\ Journal of Arts, Literature, Humanities and Social Sciences www.jalhss.com \\ Volume (54) July 2020 \\ العدد (54) يوليو 2020}

"Yalena is a very brave little girl. It is not easy to be the daughter of a soldier." (Ringo J., Evans L. "The Road to Damascus").

“...I could tell you were an honest man. There weren't so many left." (Lodge D. "Paradise News").

It should be noted that the above character traits are universal. Accordingly, in this case we are not talking about the monopoly possession of one or another ethnic community with these traits, but rather about differences in the forms (shades, styles, etc.) of their manifestation and their assessment of the Russian and English linguistic personality.

If in English examples the assessment of a person's moral qualities - traditional virtues is explicitly expressed ("you are an honest man", "you've been kind", "she is very brave"), then in Russian sayings of praise and compliment of this variety of describe traits are also appreciated, but not always called directly, but can be positioned as traits that distinguish the recipient of a compliment from other people.

E.g. «Это очень хороший мальчик. Серьезный, добрый, честный» (Маринина А. «Стечение обстоятельств»).

«Что мне еще в тебе, Матвей, нравится, так это то, что ты в партии модные не стремишься, на себя только и надеешься» (Доценко В. «Правосудие Бешеного»).

«Ты мне нравишься: умен, образован, предприимчив, дорогу другим не переступаешь, но и свое не отдашь» (Доценко В. «Правосудие Бешеного»).

«С работой она справлялась не хуже мужиков, не знала жалости ни к себе, ни, конечно же, к врагу» (Вересов Д. «Крик ворона»).

«Девка ты крепкая, сноровистая, из себя видная» (Вересов Д. «Крик ворона»).

As it can be seen, in these Russian examples, various shades of manifestation of kindness, fortitude, courage, and industriousness are noted.

In the English communicative culture, compliments are not frequent, indicating that the interlocutor has matured, matured, in contrast to Russian communication:

E.g. «Крепкий ты стал, Миколай, заматерел, - одобрительно сказал отец» (Алешкин П. «Русская трагедия»).

The Russian respect for courage, strength, in our opinion, is a reflection of the historical past of the Russian people, and is still considered worthy of praise.

Among the compliments that evaluate a person's abilities and professionalism and occupy third place according to the degree of their particular use in English communication, the most common compliment is a high level of competence in work: E.g. "That's very commendable of you, my dear. Such initiative and patriotism! I'm sure the girls... will be delighted to hear that you're doing your part to rebuild our lovely world." (Ringo J., Evans L. "The Road to Damascus").

The latter example, moreover, demonstrates the high sense of "social responsibility" among the British mentioned by S. Madariaga (Serebryakova, 2002).

English compliments of this targeted orientation are detailed, i.e. grammatically complete sentences are used. The speaker seeks to express his thought as accurately as possible, which is difficult to do, confining himself to short jerky phrases. This is primarily due to the sphere of communication in which these speech acts are used. 


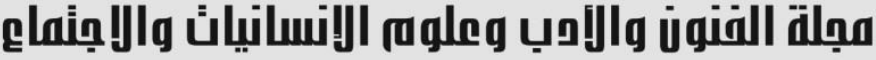 \\ Journal of Arts, Literature, Humanities and Social Sciences www.jalhss.com \\ Volume (54) July 2020 \\ العدد (54) يوليو 2020}

Praise for successfully completed work, adequately performed duties are most often accepted in a conversation with superiors, colleagues or partners, i.e. in official business communication. The assessed actions of the interlocutor are often complex, therefore, the speaker does not describe them, but replaces the verbs "to do" and "to make":

E.g. "We appreciate very much what you've done," I said to the old lady." (Moody A. "Coming of Age in Mississippi").

These examples serve as a kind of confirmation that, as we noted earlier, Russians primarily value honest and responsible performance of their duties, and not initiative and independence, as is observed in English communication. Perhaps this is really the understanding of the hard work and professionalism of the Russian language personality.

Less often than in English, Russian communicative culture also uses compliments to human intellectual abilities. Speech acts of this kind in both cultures can characterize both the general intellectual level of the recipient of a compliment and the individual nuances of his mental abilities - the ability to think logically, wisdom, analytical mindset, etc.:

E.g. «Конечно, ты необычный человек. Твои знания огромны, а искусство находить необычные выводы поразительно» (Росоховатский И. «Командир»).

"She's a very intelligent child, and has a nice little manner of her own" (Alcott L. "Eight Cousins").

In Russian and English communicative cultures, general appraisal so-called generalizing compliments characterizing the personality as a whole are often used. Moreover, the results of the study indicate a higher frequency of their use, compared to other types of compliments, in English speech communication:

E.g. "She is a remarkable girl" (Updike J. "Couples").

"Do you have any idea how remarkable you are, dear lady?" (Ringo J., Evans L. "The Road to Damascus").

\section{Discussions}

Based on the purpose of our study, one of the methods for achieving which is the comparative method, we paid special attention to the study of the national character of the Russian and English language personality. Peculiarities of a national character are reflected in the cultural and speech traditions of the people, and they, in turn, are embodied in the system of general requirements for speech and speech behavior that has historically developed in a particular culture and reflects the system of its ethical and aesthetic values. So, having compiled psychological portraits of representatives of the Russian and English nations, we came to the conclusion that the dominant features of the Russian national character are simplicity, kindness, openness, sincerity, spontaneity of behavior, honesty and collective consciousness. These are also the main characteristics of Russian communicative behavior. 


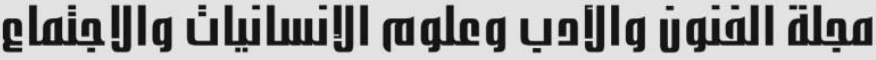 \\ Journal of Arts, Literature, Humanities and Social Sciences www.jalhss.com \\ Volume (54) July 2020 \\ العدد (54) يوليو 2020}

As for the Englishman, his inherent independence, bordering on alienation, restraint, individualism, the desire to hide emotions, at first glance, run counter to the tendency of the English language personality to explicit exaggeration, increased expressiveness and expressiveness in expressions of praise / compliment. This paradox of an English national character is explained by a conscious, not natural and spontaneous, but planned demonstration of emotions. But, as the conclusions proposed in our work have shown, this does not give rise to a statement about the total hypocrisy and insincerity of the British. Everything is explained by the fact that the English communicant focuses more on the feelings of others, he is required to be extremely attentive to others and their feelings. Hence the intentional manifestation by the English language personality of an increased interest in the interlocutor, a high degree of expressiveness, which is more likely a manifestation of emotiveness than emotionality.

A conscious demonstration by the English language personality of emotions is used, rather, in order to influence others, demonstrate loyalty, prevent a possible conflict, etc.

The emotionality of English communication inevitably manifests itself in the language means of designing English speech acts of praise / compliment. The British use numerous superlative units, intensifiers, expressive emotional-evaluative units.

The Russian communicative culture is more emotional, i.e. the Russian language personality is characterized by a spontaneous, natural demonstration of emotions, which is used, rather, in order to demonstrate solidarity with the interlocutor, to achieve effective communication. Of course, Russian communication is also characterized by emotion, but it plays a much smaller role than in English speech communication.

The less, compared with the English, emotion of Russian compliments is also manifested in the means of the linguistic design of Russian speech acts. Nevertheless, in Russian speech communication no less often than in English, intensifiers are used that give speech acts an emotionally expressive tone and exclamatory intonation.

Under the influence of the amplification law, in both Russian and English speech acts of praise / compliment, hyperbole, comparisons, and gradation are often used.

After analyzing the results of studies conducted in this area, we found out that compliments about the appearance of a person prevail in Russian communication culture, and compliments about the inner, moral qualities of a person prevail in English. The main factors determining these national-cultural differences in the use of compliments, in our opinion, are the non-identity of hierarchical value systems in comparable linguistic cultures and differences in the principles and norms of Russian and English etiquette culture.

Given the differences in the degree of frequency of the Russian and English linguistic personality using compliments of their appearance, internal qualities and intellectual abilities of the interlocutor, the frequency of using statements evaluating the other advantages of the addressee in the two communicative cultures is approximately the same. Moreover, the form and means of linguistic registration of such statements in two linguistic cultures are not identical. 


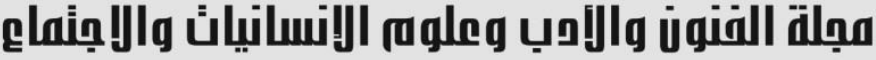 \\ Journal of Arts, Literature, Humanities and Social Sciences www.jalhss.com \\ Volume (54) July 2020 \\ العدد (54) يوليو 2020}

It is obvious that in both Russian and English communicative cultures, women are more likely to be both addressees and recipients of compliments. In both cultures, the communicative tactics of female and male compliments are manifested both at the level of choice of topics of utterances, and at the level of choice of language units. In the language of men complimenting women, there is an emotionally-evaluative vocabulary that characterizes the "feminine" principle, namely tenderness, softness, sophistication, elegance, etc. Similar vocabulary is also used by women in relation to women and men, but compliments of this kind are not frequent and typical in communication between men. Men, making compliments to each other, usually use vocabulary of a different emotional and evaluative tonality, which is characterized by a "masculine" principle: strength, firmness, persuasiveness, and prudence.

In both Russian and English communicative cultures, compliments can directly indicate a person's worth (direct compliments) or indirectly (indirect compliments). We determined the general characteristics of these two types of speech act in Russian and English speech behavior - the general composition of the speech act, a list of objects and existing subspecies of such compliments. As for the complimentantithesis, based on the material of the studied units, we assume that it is not common in English speech communication, which also, in our opinion, is explained by the etiquette nature of the compliment in the English communicative culture, for which the compliment-antithesis may seem impolite and too familiar.

A Russian linguistic personality, if he shows some kind of verbal reaction to a compliment, then, as a rule, agrees with him, accompanying his consent with a rational motivation for his justice. The native speaker of English is inclined to demonstrate joy, pleasure from the received compliment and gratitude, which we also explain by the emotionality of English communication and the desire to follow the prescribed speech etiquette.

In its most general form, the verbal response to a compliment in both cultures can be expressed by accepting a compliment or disagreement with it. The latter, in turn, can be caused by obvious flattery, irony and ridicule, negative comparisons, the speaker's excessive familiarity, the recipient's uncertainty about the sincerity of the compliment, the antipathy of the addressee to the addresser, or the modesty of the addressee.

\section{Conclusion}

In this paper, we analyzed the features of praise / compliment speech acts from the perspective of the theory of speech acts, and also analyzed the object orientation, the compliment vector, implementation methods, and language design of these speech acts in Russian and English communicative cultures.

Thus, from the analysis of factual material, it becomes obvious that the basis of speech acts of praise / compliment is a frame that includes images of the addressee (subject of the compliment), the addressee or a third person who is not in the communicative space, as well as the object (object) of the compliment. In general, the list of objects of speech acts of praise / compliment is quite diverse, but studies 


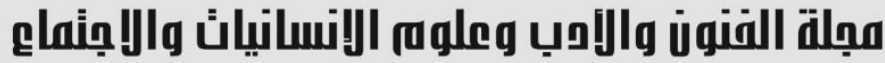 \\ Journal of Arts, Literature, Humanities and Social Sciences \\ www.jalhss.com \\ Volume (54) July 2020 \\ العدد (54) يوليو 2020}

conducted in this area allow us to highlight the most typical object orientation of compliments for Russian and English communicative cultures. Based on the results of our study, we can conclude about the different manifestations of appraisal in the communicative consciousness of Russian and English and about the differences in the focus of compliment in the two communicative cultures. In communication, Russians mainly pay attention to external factors, which confirms the productivity in the Russian communicative culture of compliments to the appearance of a person, praise for a job well done. For the British, internal factors play a large role, which is manifested in the frequent use of compliments to the moral qualities and intellectual abilities of man.

\section{References}

1. Alcott, L. (2011). Eight Cousins. Retrieved from https://www.amazon.com/Eight-Cousins-Louisa-May-Alcott/dp/1466272937

2. Austin, J. (1962). How to Do Things with Words. Oxford: Oxford University Press

3. Leech, G. (1983). Principles of Pragmatics. Longman: Longman Group Limited.

4. Lessing, D. (1963). England Versus England. Retrieved from https://librebook.me/england_versus_england

5. Lodge, D. (1991). Paradise News. Retrieved from https://books.google.iq/books/about/Paradise_News.html?id=v14rAAAAYAA J\&redir_esc $=\mathrm{y}$

6. Moody, A. (1968). Coming of Age in Mississippi. Retrieved from https://books.google.iq/books/about/Coming_of_Age_in_Mississippi.html?id= gHh7bPqJw6UC\&redir_esc=y

7. Ringo J., Evans L. (2005). The Road to Damascus. Retrieved from https://www.simonandschuster.com/books/The-Road-to-Damascus/JohnRingo/Bolo/9780743499163

8. Searle, J, Vanderveken, D. (1985). Foundations of Illocutionary Logic. Cambridge: Cambridge University Press.

9. Searle, J. (1969). Speech Acts: An Essay in the Philosophy of Language. Cambridge: Cambridge University Press.

10. Serebryakova, R.V. (2002). Natsionalnaya spetsifika rechevykh aktov komplimenta $i$ pokhvaly $v$ russkoi $i$ angliiskoi kommunikativnykh kulturakh [National specificity of compliment and praise speech acts in Russian and English communicative cultures]: dis. ... kand. filol. nauk: 10.02.19 / R.V. Serebryakova. Voronezh. 202 s.

11. Updike, J. (1968). Couples. Retrieved from https://bookdepository.live/show/book/11662/couples/12194019/beacc068/5b $61 \mathrm{~d} 24 \mathrm{fa} 9 \mathrm{f} 8 \mathrm{c} 9 \mathrm{a} /$ 


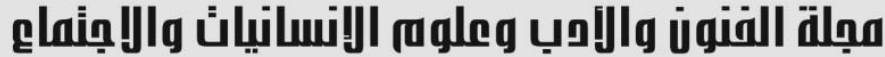

Journal of Arts, Literature, Humanities and Social Sciences

www.jalhss.com

Volume (54) July 2020

العدد (54) يوليو 2020

12. Wharton,

E.

(1917).

Summer.

Retrieved

from https://books.google.iq/books?id=mpWJDwAAQBAJ\&pg=PT6\&lpg=PT6\&d $\mathrm{q}=$ Wharton $+\mathrm{E} .+\% \mathrm{E} 2 \% 80 \% 9 \mathrm{CSummer} \&$ source $=\mathrm{bl} \&$ ots $=$ YtXf6pQtVq\&sig $=\mathrm{A}$ CfU3U0OnaAbSfOUA13OxLI1u6XeETpe1g\&hl=ru\&sa=X\&ved=2ahUKEwj ptqqyxpDqAhVHT8AKHa-

EC_AQ6AEwBXoECBMQAQ\#v=onepage \&q=Wharton\%20E.\%20\%E2\%80 $\% 9 \mathrm{CSummer} \& \mathrm{f}=$ false

13. Алешкин, П. (2003). Русская трагедия. Retrieved from https://royallib.com/book/aleshkin_petr/russkaya_tragediya.html

14. Антипов, Г.А., Донских, О. А., Марковина, И. Ю., Сорокин, Ю. А.(1989). Текст как явление культуры. Новосибирск: Наука.

15. Вересов, Д. (2002). Крик ворона. Retrieved from https://libking.ru/books/det-/thriller/309438-dmitriy-veresov-krik-vorona.html

16. Глазунова, О.И. (2000). Логика метафорических преобразований. Спб.

17. Доценко, В. (2018). Правосудие Бешеного. Retrieved from http://loveread.ec/view_global.php?id=20976

18. Маринина, А. (1997). Стечение обстоятельств. Retrieved from http://loveread.ec/read_book.php?id=2725\&p=1

19. Росоховатский, И. (1997). Командир. Retrieved from https://www.litmir.me/br/?b=37396

20. Сулейменова, Э.Д. (1989). Понятие смысла в современной лингвистике. Алма-ата: Мектеп.

21. Тер-Минасова, С.Г. (2000). Язык и межкультурная коммуникация: учебное пособие. Moscow: Слово/Slovo. 